\title{
Effect of 3 mol\% Yttria Stabilized Zirconia Addition on Structural and Mechanical Properties of Alumina-Zirconia Composites
}

\author{
M. A. Gafur ${ }^{1 *}$, Md. Saifur Rahman Sarker², Md. Zahangir Alam³ ${ }^{3}$ M. R. Qadir ${ }^{1}$ \\ ${ }^{1} \mathrm{PP} \&$ PDC, BCSIR, Dhaka, Bangladesh \\ ${ }^{2}$ Department of Chemistry, Kurigram Govt. College, Kurigram, Rangpur, Bangladesh \\ ${ }^{3}$ Department of ACCE, Dhaka University, Dhaka, Bangladesh \\ Email: ${ }^{\star d}$ _r_magafur@bcsir.gov.bd
}

How to cite this paper: Gafur, M.A., Sarker, Md.S.R., Alam, Md.Z. and Qadir, M.R. (2017) Effect of $3 \mathrm{~mol} \%$ Yttria Stabilized Zirconia Addition on Structural and Mechanical Properties of Alumina-Zirconia Composites. Materials Sciences and Applications, 8, 584-602. https://doi.org/10.4236/msa.2017.87041

Received: April 10, 2017

Accepted: July 21, 2017

Published: July 24, 2017

Copyright $\odot 2017$ by authors and Scientific Research Publishing Inc. This work is licensed under the Creative Commons Attribution International License (CC BY 4.0).

http://creativecommons.org/licenses/by/4.0/

\section{c) (i) Open Access}

\begin{abstract}
Alumina-Zirconia $\left(\mathrm{Al}_{2} \mathrm{O}_{3}-\mathrm{ZrO}_{2}\right)$ composites especially Zirconia Toughened Alumina (ZTA) shows better mechanical properties over alumina. $\mathrm{Al}_{2} \mathrm{O}_{3}-\mathrm{ZrO}_{2}$ composites were prepared by powder compaction method varying $3 \mathrm{~mol} \% \mathrm{yt}$ tria stabilized zirconia $\left(3 \mathrm{Y}-\mathrm{ZrO}_{2}\right)$ content from 0 to $20 \mathrm{vol} \%$ using small amount of $\mathrm{MgO}$ as sintering aid. The composites were sintered for two hours in air at $1580^{\circ} \mathrm{C}$. At this temperature maximum density was achieved $99.31 \%$ of theoretical density for composite containing $20 \mathrm{vol} \% 3 \mathrm{Y}-\mathrm{ZrO}_{2}$. Density measurement of sintered composites was carried out using Archimedes's method. Hardness and fracture toughness measurement was carried out using Vickers indentation. Phase content and $\mathrm{t}-\mathrm{ZrO}_{2}$ retention were detected by means of X-ray diffraction (XRD). Microstructure of the composites and grain size of alumina and zirconia was determined by Scanning Electron Microscopic (SEM) analysis. Maximum microhardness (17.46 GPa) was achieved for composite containing $5 \mathrm{vol} \% \mathrm{ZrO}_{2}$ and maximum flexural strength (684.32 $\mathrm{MPa})$ and fracture toughness $\left(10.33 \mathrm{MPam}^{0.5}\right)$ was achieved for composite containing $20 \mathrm{vol} \%$ of $3 \mathrm{Y}-\mathrm{ZrO}_{2}$. The aim of the present work is to investigate the optimum $3 \mathrm{Y}-\mathrm{ZrO}_{2}$ content for obtaining maximum density, microhardness, flexural strength and fracture toughness of $\mathrm{Al}_{2} \mathrm{O}_{3}-\mathrm{ZrO}_{2}$ composites.
\end{abstract}

\section{Keywords}

Alumina-Zirconia Composites, Sintering, $\mathrm{t}-\mathrm{ZrO}_{2}$ Retention, Grain Size

\section{Introduction}

Alumina is a suitable candidate for preparing engineering ceramics because of its several inherent properties such as low thermal conductivity, comparatively high 
thermal expansion coefficient, high hardness and pronounced chemical stability. Alumina ceramics is used for biomedical applications. It has been developed as an alternative to surgical metal alloys for total hip prosthesis and tooth implants. As an inert bioceramic $\mathrm{Al}_{2} \mathrm{O}_{3}$ is used in load bearing hip prosthesis and dental implants in dense and pure state for its corrosion resistance and high were resistance. In the early 70's bioceramics were employed to perform singular biologically inert roles, such as to provide parts for bone replacement. The realization that cells and tissues in the body perform many other vital regularity and metabolic roles has highlighted the limitations of synthetic materials as tissue substitutes. Demand of bioceramics has changed from maintaining an essentially physical function with eliciting a host response, to provide a more integrated interaction with the host. This has been accompanied by increasing demand for medical devices to improve the quality of life as well as extended durability. It is a problem for common alumina that it shows low mechanical resistance and fracture toughness [1]. Alumina-Zirconia composites have been widely studied over last two decades [2] [3] [4] [5]. It is well known that the mechanical properties of alumina ceramics can be considerably increased by the incorporation of fine zirconia particles [6] [7] [8] [9]. By improving the mechanical behavior alumina may be more widely used for various biomedical applications. AluminaZirconia composites are an important class of ceramic which exhibit high strength and toughness over alumina due to stress induced phase transformation (tetragonal to monoclinic zirconia) [10] [11] [12]. This phenomenon was first discovered by Clauson in 1976 [6]. Pure zirconia has three polymorphic (crystalline) forms: monoclinic ( $\mathrm{m}$, at low temperature), tetragonal ( $\mathrm{t}$, at intermediate temperature) and cubic (c, at high temperature) [13]. The $\mathrm{t}$ to $\mathrm{m}$ transformation is martensitic in nature. It is used to improve the mechanical properties of $\mathrm{ZrO}_{2}$ ceramics and $\mathrm{ZrO}_{2}$ particle-reinforced composites by the mechanism of transformation toughening. The $\mathrm{t}$ to $\mathrm{m}$ transformation occurs at around $950^{\circ} \mathrm{C}$ on cooling. Transformation toughening occurs because of the volume expansion occurs (3\% - 4\%) that accompanies $\mathrm{t} \rightarrow \mathrm{m}$ transformation producing a reduction in the stress intensity at the crack tip, leading to a dissipation of energy of the propagating crack. Cracks become self-limiting because an advancing crack must overcome both the energy required for material transformation associated with the volume expansion of transformed material [14] [15] [16]. The grain size of zirconia is also important for retaining t-phase in the composite. The size must be lower than a critical size to ensure the t-phase at room temperature [17]. The increased volume fraction of zirconia is also responsible to reduce the stability of the tetragonal phase. Hence, an optimum amount of zirconia addition is expected to retain the favorable amount of tetragonal content which can enhance the thermal and mechanical properties of Alumina-Zirconia composites without any grain growth during sintering [18]. When compared with single phase $\alpha-\mathrm{Al}_{2} \mathrm{O}_{3}$, Alumina-Zirconia composites offers high hardness of $\mathrm{Al}_{2} \mathrm{O}_{3}$ matrix, coupled with improvements in fracture toughness. Because $\mathrm{t}-\mathrm{ZrO}_{2}$ particles are present within the matrix, overstabilization of tetragonal zirconia phase is 
also a problem. If the tetragonal phase is overstabilized, the stress required for transformation in the high stress region around a crack tip may be higher than the fracture toughness. As a result the fracture toughness of the composite will be low, similar to that of alumina. It has been observed that a mixture of tetragonal and monoclinic zirconia gives the highest toughness in zirconia toughened alumina [19]. In this investigation, a small amount of sintering aid ( $\mathrm{MgO})$ was used. The mechanical properties are also dependent on relative distribution of $\mathrm{Al}_{2} \mathrm{O}_{3}$ and $\mathrm{ZrO}_{2}$ matrix [20]. For getting homogeneous microstructure of the composite homogeneous distribution of $\mathrm{Al}_{2} \mathrm{O}_{3}$ and $\mathrm{ZrO}_{2}$ is very much essential. Densification is another important factor for obtaining better mechanical properties. Composite with low density show poor mechanical properties. So, proper processing route should be followed for getting high mechanical properties. Relative density of Alumina-Zirconia composites increases with increasing sintering temperature but at the same time the fraction of retained $\mathrm{t}-\mathrm{ZrO}_{2}$ decreases probably due to the combined effect of low matrix constraint provided by the porous compacts as well as due to an increase in grain size [21]. So, optimization of sintering temperature plays a vital role on properties of composite. Sintering temperature was optimized as $1580^{\circ} \mathrm{C}$.

Introduction of a small amount of sintering aid $(\mathrm{CaO}, \mathrm{MgO})$ in the ceramic process enhances the mass transport during solid state sintering so that ceramic reached full density at low temperature. Moreover decreasing grain growth a stronger ceramic was obtained [7]. To fulfill this purpose $0.2 \mathrm{wt} \% \mathrm{MgO}$ was used as sintering aid in sample preparation. To obtain homogeneous structure of the composite and high density ceramic body slurry was prepared in ethanol media and powder compaction method was adopted for sample preparation in this investigation which may be an alternative design for preparing $\mathrm{Al}_{2} \mathrm{O}_{3}-\mathrm{ZrO}_{2}$ composites. An alternative sintering schedule has also been followed in the present study.

\section{Experimental Procedure}

\subsection{Sample Preparation}

Nano crystalline $\alpha$-alumina powder (purity of $99.9 \%$, crystal size $40 \mathrm{~nm}$, average particle size $150 \mathrm{~nm}$, Advance materials, USA), 3 mol\% yttria stabilized zirconia powder (purity 99.9\%, crystal size $30-60 \mathrm{~nm}$, Advance materials, USA) and magnesium oxide (99\%, RCL Labean Ltd, Bangkok, Thiland) powders were thoroughly mixed to obtain a homogeneous distribution. In doing so, proper amount of $\mathrm{Al}_{2} \mathrm{O}_{3}, \mathrm{ZrO}_{2}$ and $\mathrm{MgO}$ was taken in a HDPE pot. Wet milling was carried out for 24 hours in ethanol media in a motor driven pot mill using yttria stabilized zirconia balls as grinding media. $3 \mathrm{Y}-\mathrm{ZrO}_{2}$ was added into alumina from $0,2,5,10,15$ and 20 vol\%. $0.2 \mathrm{wt} \%$ of magnesium oxide was also added to the alumina-zirconia mixture. The slurry of the powder mixtures was dried in an vacuum oven (VO400, Memmert, Germany) at $90^{\circ} \mathrm{C}$ for 6 hours and 5\% PVA (polyvinyl alcohol) solution was added as a binder. The mixture was milled for uniform mixing and again dried and screened. The dried blend was unidirec- 
tionally pressed into pallets at $210 \mathrm{MPa}$ using Universal Testing Machine (FS 300 KN, Testometric Co. Ltd. England).

In the single stage sintering schedule (Figure 1) depicted below that there was a holding period of three hours at $600^{\circ} \mathrm{C}$ for binder removal. The samples were finally sintered at $1580^{\circ} \mathrm{C}$ for two hours in air according to sintering schedule using high temperature furnace (Z18-40, Micropyretics Heaters International, USA). The sintered samples were used for characterization. For all sample same sintering schedule was maintained.

\subsection{Measurements}

Density of the sintered sample was measured by Archimedis' law using the following equation:

$$
\rho_{s}=\frac{m_{s} \rho_{w}}{m_{s}-m_{w}}
$$

where $\rho_{s}=$ sintered density, $\rho_{w}=$ water density, $m_{s}=$ mass of sintered pellet, $m_{w}=$ mass of pellets in water.

The percentage of total porosity $\varphi$ was calculated from the bulk density and the theoretical density $\rho_{o}$ according to the standard formula [22]:

$$
\varphi=\left(1-\frac{\rho}{\rho_{o}}\right) \times 100
$$

where, $\varphi=$ the total porosity of the sample, $\rho=$ density of sintered pellet and $\rho_{o}=$ theoretical density for samples.

Microhardness of the composites was measured by Vickers indentation using Micro-hardness Tester (HMV-2T, Shimadzu Corporation, Japan). The applied load was $19.614 \mathrm{~N}$ for 6 second over polished surface. The values of microhardness were calculated from the following equation [8]:

$$
H_{v}=0.0018544\left(P / d^{2}\right)
$$

where, $H_{V}=$ Vickers hardness $(\mathrm{GPa}), P=$ applied load $(\mathrm{N}), d=$ arithmetic mean of the two diagonal length $(\mathrm{mm})$

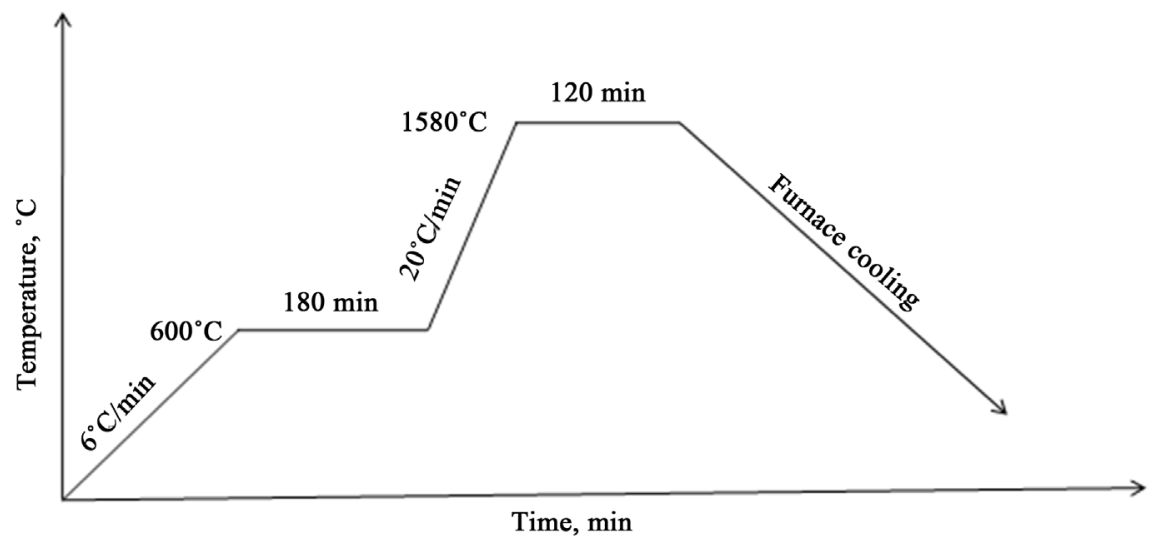

Figure 1. Sintering schedule. 
The porosity dependence Elastic Modulus can also be measured using DeweyMackenzie relation [18]:

$$
E=E_{o}(1-2 \varphi)
$$

where, $E$ is the effective elastic modulus of porous composites. $E_{o}$ is the elastic modulus of the dense composite and $\varphi$ is the porosity of the sample.

Fracture toughness of the composite was measured by Vickers indentation using equation [23]:

$$
K_{I C}=0.016\left(E / H_{v}\right)^{0.5} P / C_{o}^{1.5}
$$

where, $K_{I O} H_{r}, E, P$ and $C_{o}$ stand for fracture toughness(Gpa), Vickers hardness $(\mathrm{GPa})$, elastic modulus(GPa), indentation load $(\mathrm{MN})$ and radial crack length(m), respectively. In this case applied load was $20 \mathrm{~kg}$ for 15 second (DVK-2, MATSUZAWA, Japan). All fracture surfaces were observed in an optical microscope (NMM-800TRF, MTI Co., USA). Before indentation the specimen surface was polished successively using 1200 and 4000 grit SiCpaper, respectively. Following this, the samples were polished in $6 \mu \mathrm{m}$ and $1 \mu \mathrm{m}$ diamond paste on a texmet cloth.

Phase identification was performed on sintered surface by X-ray diffractometry (XRD) with CuKa radiation $(\lambda=1.54046 \AA)$ in D8 Advance diffractometer (BRUKER AXS GmbH, Germany) using $40 \mathrm{KV}$ voltage and $40 \mathrm{~mA}$ tube current. The scanning speed was maintained $2^{\circ} / \mathrm{min}, 2 \theta=20^{\circ}-70^{\circ}$ range. The volume fraction of monoclinic zirconia $\left(V_{m}\right)$ was calculated according to the following equation [24].

$$
V_{m}=\frac{I_{(\overline{1} 11)_{m}}+I_{(111)_{m}}}{I_{(\overline{1} 11)_{m}}+I_{(111)_{m}}+I_{(111)_{t}}}
$$

where $I$ is the integral intensity and the subscripts $\mathrm{m}$ and $\mathrm{t}$ refer to the monoclinic and tetragonal phase, respectively.

Microstructure of the sample was observed by Scanning Electron Microscopy (SEM). The polished samples were sputter coated with platinum for 2 - 3 minute to make the surface conducting. The specimens were observed by SEM (JEOL-6490, Japan) in secondary electron (SE) mode at $20 \mathrm{KV}$ accelerating voltage. The grain size of alumina and zirconia were measured by comparison method.

\section{Results and Discussion}

\subsection{Density and Porosity}

Density and porosity are important parameters on which mechanical properties depend. Composites with higher density and lower porosity offer better mechanical properties [8]. The presence of porosity can reduce fracture toughness by the reduction of the resistant area by the effect of stress concentration in the pores. So reduction of porosity and production of composite with higher density is an important factor to obtain better mechanical properties. Homogeneous 
distribution of different phases (alumina, zirconia, magnesia) in the mixture can enhance the densification process. High compaction pressure $(210 \mathrm{Mpa})$ was used to obtain compact green sample.

Density and porosity of Alumina-Zirconia composites (sintered) as a function of vol\% of $3 \mathrm{Y}-\mathrm{ZrO}_{2}$ content are presented in Figure 2 and Figure 3, respectively.

The density increases due to addition of dense powder (the density of zirconia is higher than that of alumina) and due to removing the pores between the powder. From SEM analysis it was observed that addition of $3 \mathrm{Y}-\mathrm{ZrO}_{2}$ led to

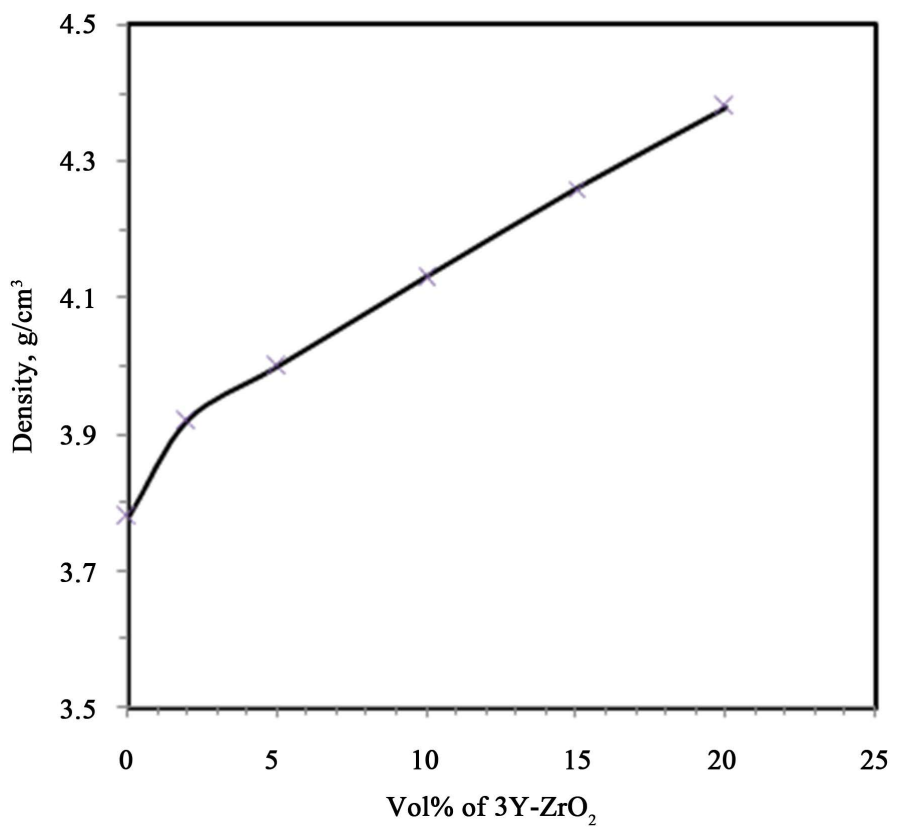

Figure 2. Effect of $3 \mathrm{Y}-\mathrm{ZrO}_{2}$ addition on density of $\mathrm{Al}_{2} \mathrm{O}_{3}-\mathrm{ZrO}_{2}$ composites.

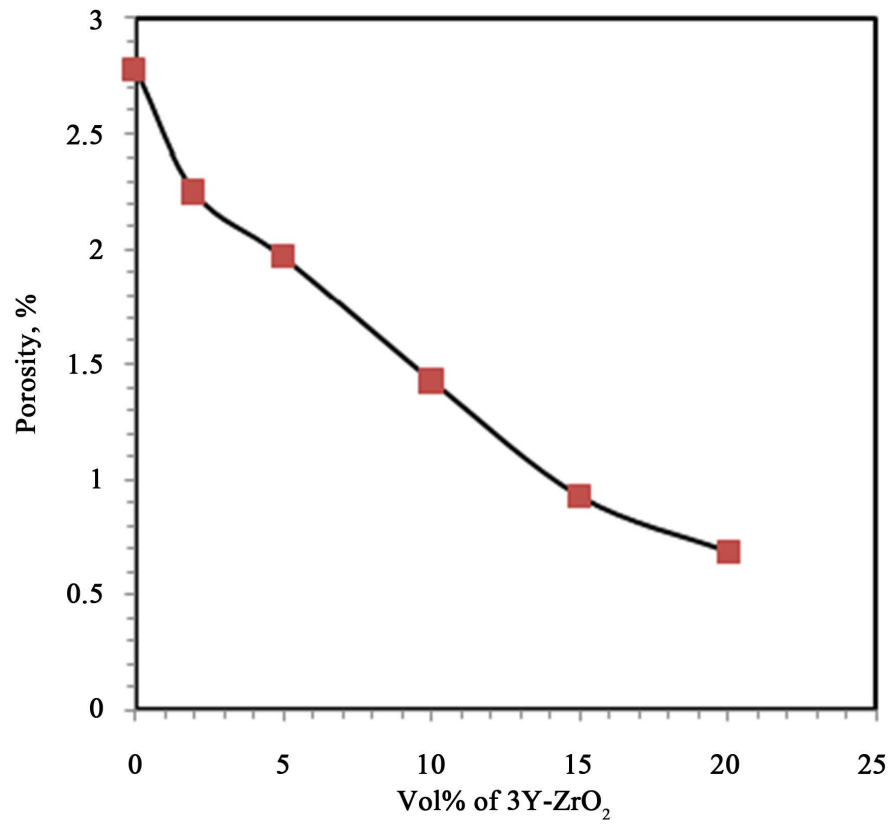

Figure 3. Effect of $3 \mathrm{Y}-\mathrm{ZrO}_{2}$ addition on porosity of $\mathrm{Al}_{2} \mathrm{O}_{3}-\mathrm{ZrO}_{2}$ composites. 
decrease in grain size of alumina, which is also responsible for increase in density. It is well known that densification of powdered particle during sintering is a thermally assisted phenomenon. Thermal energy helps to diffuse atom and thus bonding is developed between the adjacent particles. With the continual supply of thermal energy more and more contact points are created between the particles and the intervening porosity diffuses out of the contact area. Hence a substantial increase in density resulted and porosity of the composite is reduced. In the mean time the existing grains inside the particle have an opportunity to grow in order to minimize the overall energy of the system. Thus densification and grain growth occurs simultaneously. Density of composite also depends on $\mathrm{t}-\mathrm{ZrO}_{2}$ retention, because transformation of $\mathrm{m}-\mathrm{ZrO}_{2}$ to $\mathrm{t}-\mathrm{ZrO}_{2}$ leads to volume compression. For pure alumina $95.2 \%$ of theoretical density was achieved (porosity $4.80 \%$ ) whereas $99.31 \%$ of theoretical density was achieved for composite containing $20 \mathrm{vol} \%$ of $3 \mathrm{Y}-\mathrm{ZrO}_{2}$. This density was the maximum density where the porosity was $0.69 \%$. The density value conforms to some previous works those used pressureless sintering technique [25] [26]. It is observed that the porosity is reduced as $3 \mathrm{Y}-\mathrm{ZrO}_{2}$ content increases. The porosity decreases due to densification of the composite and due to pore removal by secondary phase of $\mathrm{ZrO}_{2}$. This could be explained for the homogenity of the microstructure obtained in the present work as well as the small diameter and the narrow size distribution of the secondary phase.

\subsection{Vickers Hardness (Hv) and Elastic Moduluds (E)}

The Vickers hardness values of sintered Alumina-Zirconia composites as a function of vol\% of $3 \mathrm{Y}-\mathrm{ZrO}_{2}$ is represented in Figure 4.



Figure 4. Effect of $3 \mathrm{Y}-\mathrm{ZrO}_{2}$ content on hardness of Alumina-Zirconia composites. 
From Figure 4 it is observed that initially microhardness of the composite increased slightly with $3 \mathrm{Y}-\mathrm{ZrO}_{2}$ content up to $5 \mathrm{vol} \%$. After that it decreased significantly. Zirconia has lower hardness than alumina. Hence there is a general decreasing tendency in hardness values with increasing zirconia content. From the SEM analysis it was observed that grain size of alumina decreased significantly with lower $3 \mathrm{Y}-\mathrm{ZrO}_{2}$ content up to $5 \mathrm{vol} \%$ and after that the changes in grain size of alumina was not significant. Decrease in grain size of alumina may be a cause of increase in microhardness. So, maximum microhardness was obtained for composite containing $5 \mathrm{vol} \% 3 \mathrm{Y}-\mathrm{ZrO}_{2}$ due to combined effect of lower hardness of $\mathrm{ZrO}_{2}$ and decrease in grain size of alumina. In this investigation maximum hardness value (17.46 MPa) was obtained for composite containing 5 vol\% of $3 \mathrm{Y}-\mathrm{ZrO}_{2}$ and minimum hardness value (13.02 GPa) was obtained for composites containing $20 \mathrm{vol} \% 3 \mathrm{Y}-\mathrm{ZrO}_{2}$.

Values of elastic modulus of composites with $3 \mathrm{Y}-\mathrm{ZrO}_{2}$ content are presented in Figure 5. In this study elastic modulus of pure alumina was obtained 347.39 GPa. Maximum elastic modulus (350.48 GPa) was obtained for composite with 2 vol\% of $3 \mathrm{Y}-\mathrm{ZrO}_{2}$ and minimum elastic modulus (335.31 GPa) was obtained for composite with $20 \mathrm{vol} \%$ of $3 \mathrm{Y}-\mathrm{ZrO}_{2}$.

According to Tan et al. [27] elastic modulus depends on the porosities, microcrack and different phases present in the composite. They found that the elastic modulus of Alumina-Zirconia composite could be increased by the addition of $<5 \mathrm{wt} \%$ of $\mathrm{ZrO}_{2}$. They found maximum elastic modulus for containing 3 wt $\%$ of $\mathrm{ZrO}_{2}$. Similar trend was found in this investigation. When 2 vol\% $3 \mathrm{Y}-\mathrm{ZrO}_{2}$ was added to alumina the elastic modulus was slightly increased and maximum elastic modulus was obtained at this composition.

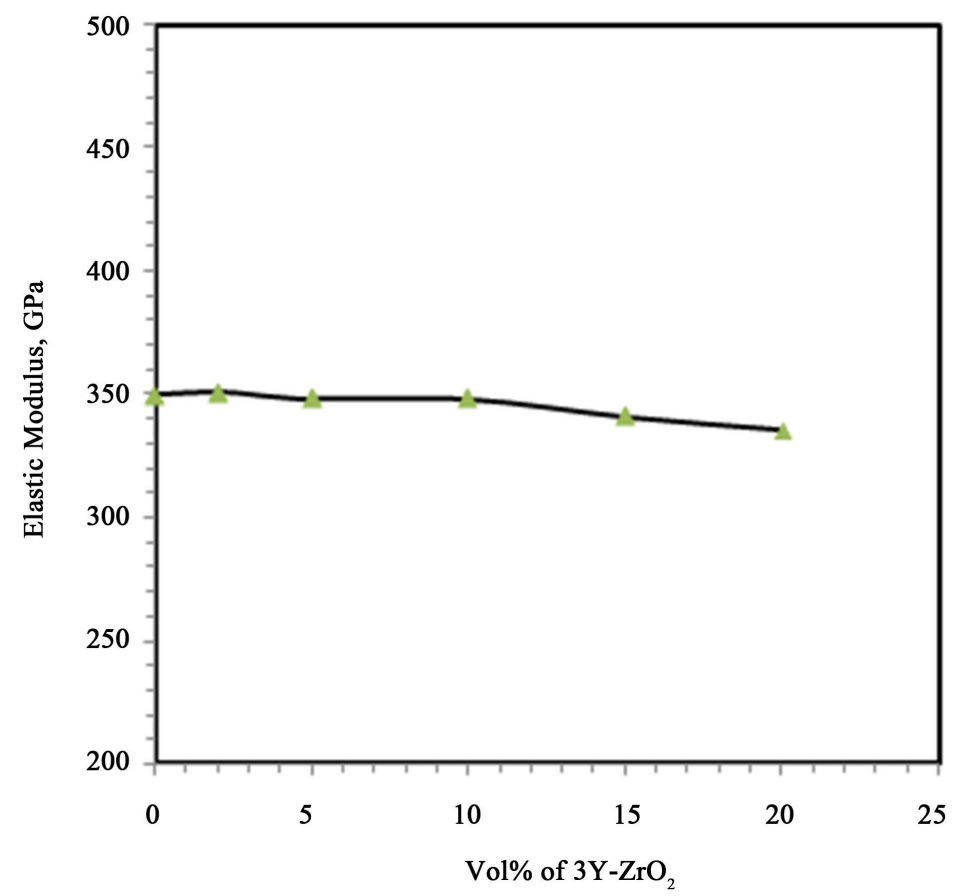

Figure 5. Effect of $3 \mathrm{Y}-\mathrm{ZrO}_{2}$ content on elastic modulus of alumina-zirconia composites. 


\subsection{Flexural Strength and Fracture Toughness}

The flexural strength and fracture toughness values of the composite as a function of $3 \mathrm{Y}-\mathrm{ZrO}_{2}$ content are presented in Figure 6 and Figure 7, respectively.

Figure 6 and Figure 7 reveal that addition of $3 \mathrm{Y}-\mathrm{ZrO}_{2}$ to alumina leads to increase in flexural strength and fracture toughness significantly. For pure alumina

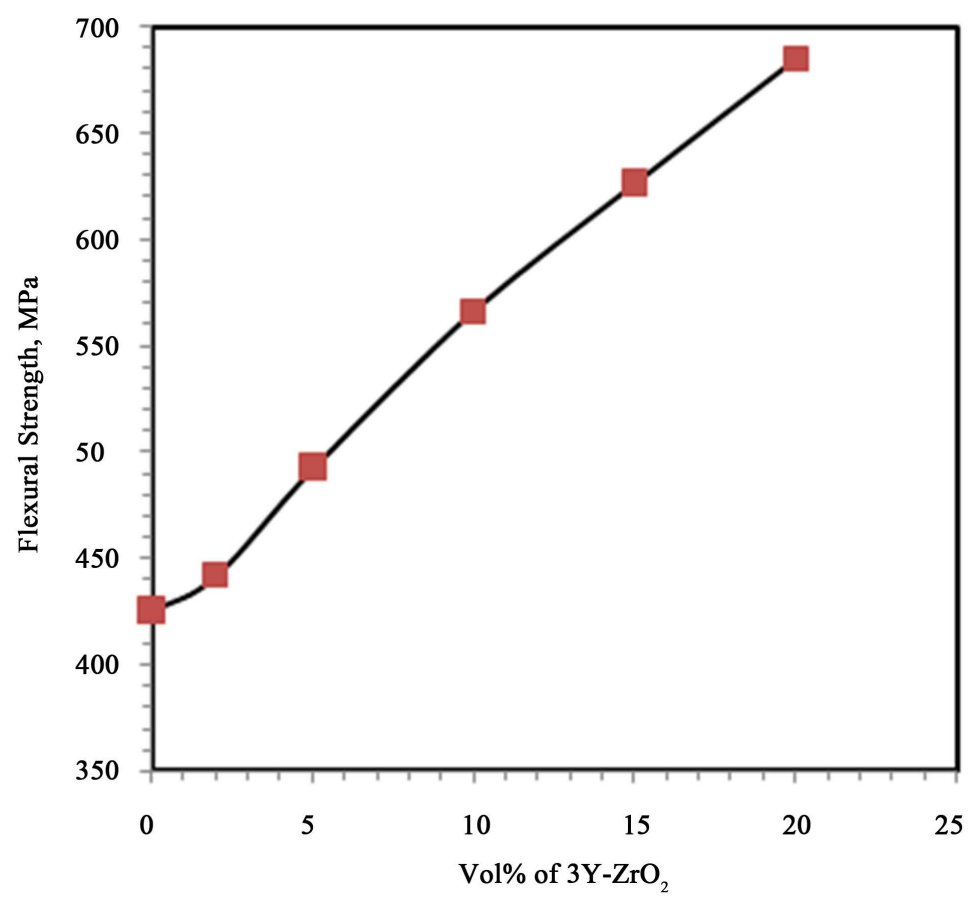

Figure 6. Effect of $3 \mathrm{Y}-\mathrm{ZrO}_{2}$ content on flexural strength of Alumina-Zirconia composites.

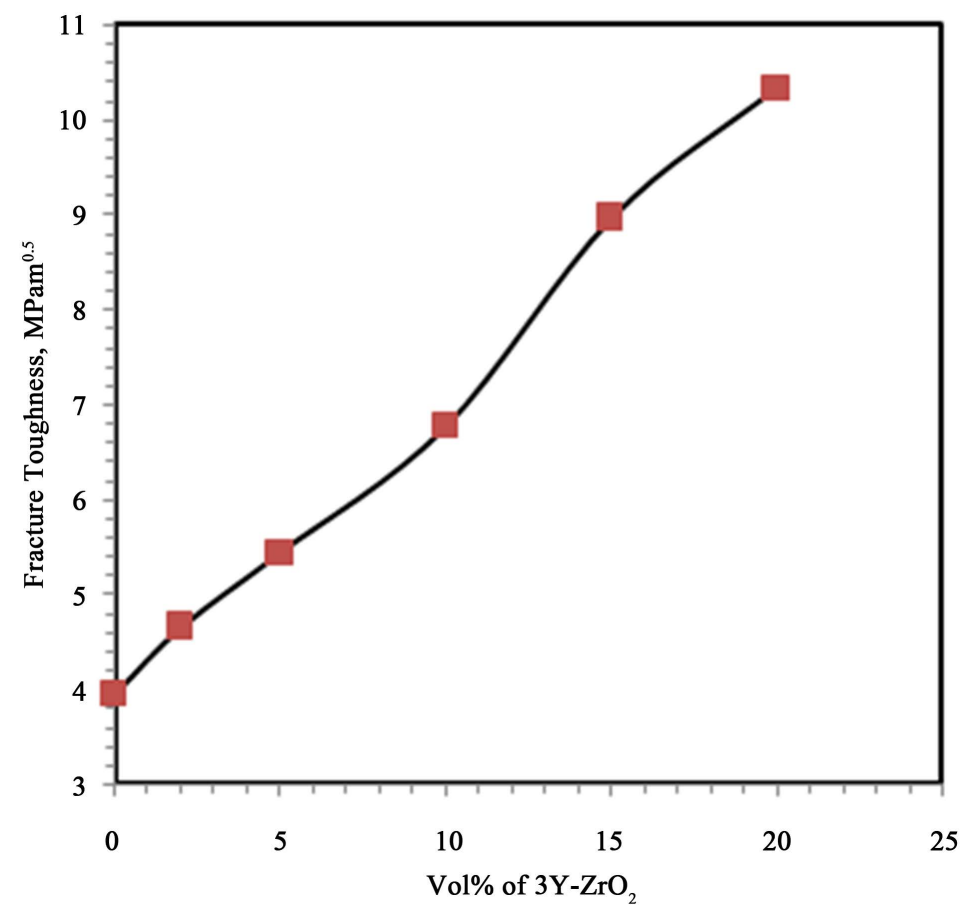

Figure 7. Effect of $3 \mathrm{Y}-\mathrm{ZrO}_{2}$ content on fracture toughness of Alumina-Zirconia composites. 
maximum flexural strength was obtained 425.23 $\mathrm{MPa}$ and fracture toughness was obtained $3.95 \mathrm{MPa} \cdot \mathrm{m}^{0.5}$. Flexural strength and fracture toughness increased with zirconia content continuously and maximum flexural strength (684.32 $\mathrm{MPa})$ and fracture toughness $\left(10.33 \mathrm{MPa} \cdot \mathrm{m}^{0.5}\right)$ were obtained for AluminaZirconia composite containing $20 \mathrm{vol} \%$ of $3 \mathrm{Y}^{-} \mathrm{ZrO}_{2}$. The increase in flexural strength and fracture toughness maybe obtained due to high density of the composite and high $\mathrm{t}-\mathrm{ZrO}_{2}$ retention at 20 vol\% $3 \mathrm{Y}-\mathrm{ZrO}_{2}$.

Improvement of mechanical properties of composites can be explained by $\mathrm{t} \rightarrow$ $\mathrm{m}$ transformation. The martensitic $\mathrm{t}$ to $\mathrm{m}$ transformation is induced by cooling or by external loading under isothermal conditions. The change increases the volume of the particle by about $3 \%-4 \%$ and produces compressive stress in the alumina matrix. These stresses in turn close the crack and act as energy barrier to further crack growth. From XRD analysis it is observed that $\mathrm{m}-\mathrm{ZrO}_{2}$ phase increase with increase in $3 \mathrm{Y}-\mathrm{ZrO}_{2}$ content and at the same time $\mathrm{t}-\mathrm{ZrO}_{2}$ retention decrease. Although the microhardness and elastic modulus of the composites slightly reduced with zirconia content the flexural strength and fracture toughness obviously improved. By incorporating proper amount of zirconia to alumina we may obtain composites with high flexural strength and fracture toughness. Similar results were also published earlier [28].

\subsection{X-Ray Diffraction (XRD) Analysis}

\subsubsection{Phase Analysis of Raw Materials}

The XRD patterns of major raw materials (alumina and stabilized zirconia) which were used for preparation of Alumina-Zirconia composites are presented in Figure 8 and Figure 9, respectively. The XRD patterns confirm their corresponding phases.

Figure 8 shows the XRD pattern of raw alumina which confirms the presence of $\alpha$-alumia (corundum) by ICDD 089-7717. $\alpha$-Alumina is the most stable

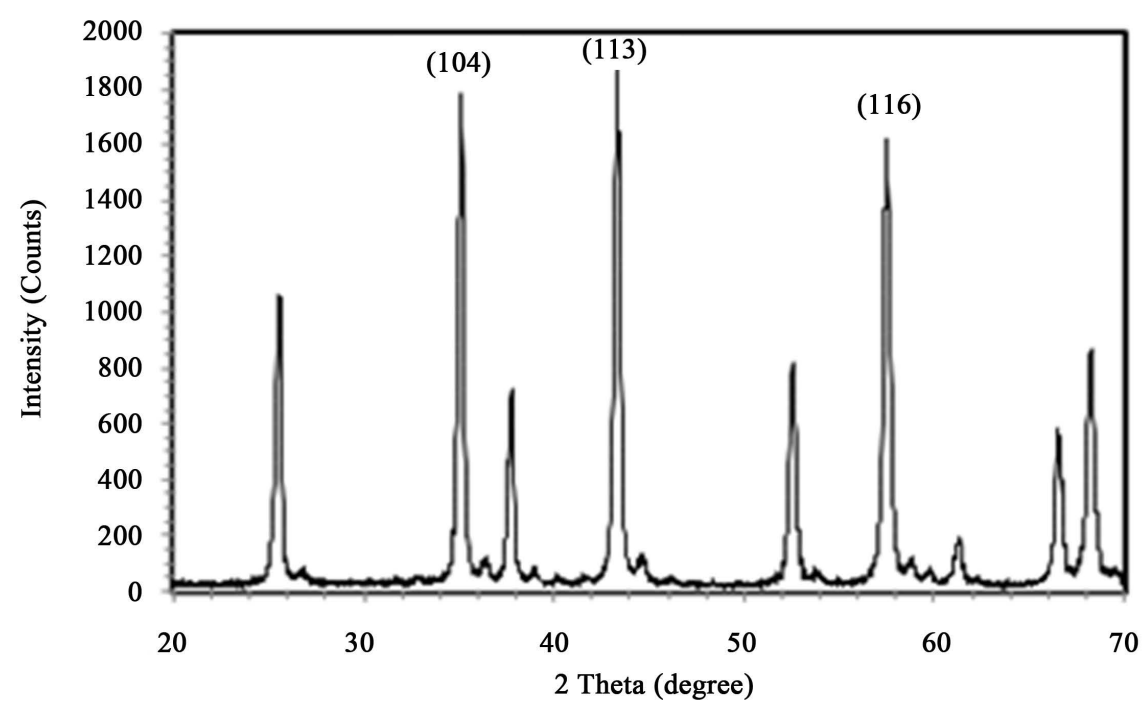

Figure 8. XRD pattern of raw alumina. 


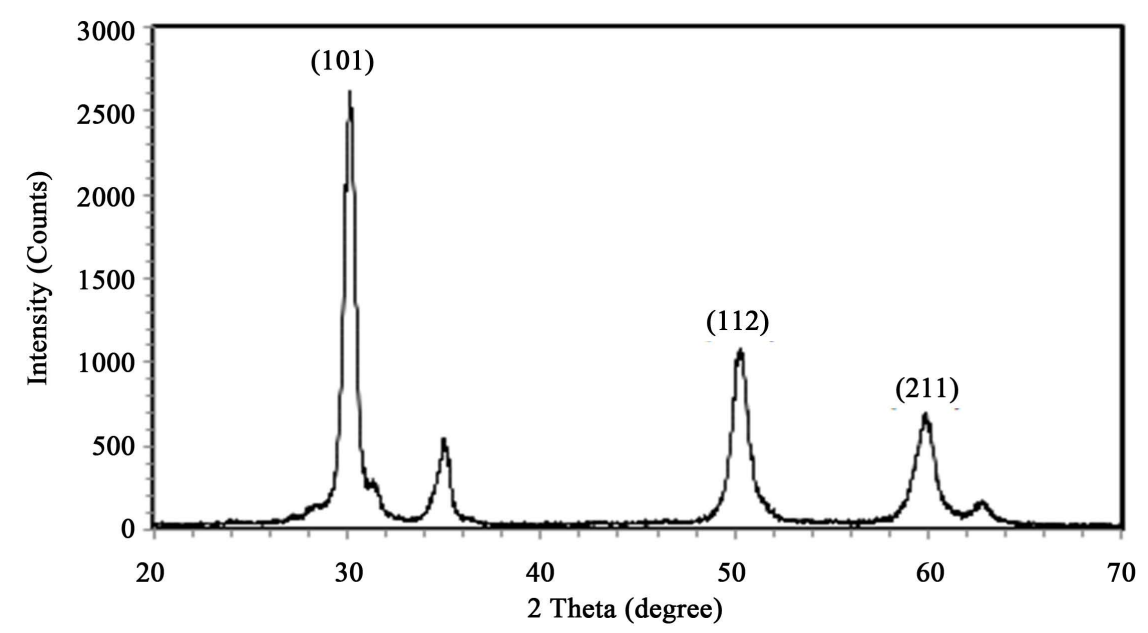

Figure 9. XRD pattern of $3 \mathrm{Y}-\mathrm{ZrO}_{2}$.

crystalline form of alumina containing rhombohedral structure. Three characteristic peaks were obtained from (104), (113) and (116) planes at $2 \theta$ values $35.11^{\circ}$, $43.32^{\circ}$ and $57.48^{\circ}$, respectively. The crystallite size of alumina was calculated $23.39 \mathrm{~nm}$.

Figure 9 shows the XRD pattern of raw 3 mol\% yttria stabilized zirconia (3Y$\mathrm{ZrO}_{2}$ ) which confirms the presence of tetragonal zirconia by ICDD 072-7115. Three characteristic peaks were obtained from (101), (112) and (211) planes at $2 \theta$ value $30.13^{\circ}, 50.29^{\circ}$ and $59.90^{\circ}$, respectively.

\subsubsection{Phase Analysis of Sintered Sample}

The XRD patterns of sintered pure alumina and Alumina-Zirconia composite of stabilized zirconia is presented in Figure 10 and Figure 11, respectively.

Figure 10 shows the XRD pattern of alumina pellet sintered at $1580^{\circ} \mathrm{C}$. As like as raw alumina the phase was identified by ICDD 089-7717 as $\alpha$-alumia (corundum). Three characteristic peaks were obtained at $2 \theta$ values $35.14^{\circ}, 43.36^{\circ}$ and $57.51^{\circ}$ which are almost similar to that that of raw alumina. But the peak intensity is significantly higher than the peak intensity of raw alumina. The crystallite size of alumina obtained was $32.48 \mathrm{~nm}$ which is also larger than that of raw alumina.

Figure 11 shows XRD pattern of Alumina-Zirconia composite containing 20 vol\% $3 \mathrm{~mol} \%$ yttria stabilized zirconia sintered at $1580^{\circ} \mathrm{C}$ which confirms the formation of multi-phase composite. Phases of $\alpha$-alumina (corundum), monoclinic zirconia $\left(\mathrm{m}-\mathrm{ZrO}_{2}\right)$ and tetragonal zirconia $\left(\mathrm{t}-\mathrm{ZrO}_{2}\right)$ were identified by ICDD 089-7717, ICDD 037-1484 and ICDD 072-7115, respectively. Though $\mathrm{t}-\mathrm{ZrO}_{2}$ was used for composite preparation, significant peaks of $\mathrm{m}-\mathrm{ZrO}_{2}$ were observed because $\mathrm{m}-\mathrm{ZrO}_{2}$ particles are present in the $\mathrm{Al}_{2} \mathrm{O}_{3}$ matrix. The improvement in strength and toughness of Alumina-Zirconia composite results from the volume expansion and shear strain arising from $\mathrm{t} \rightarrow \mathrm{m} \mathrm{ZrO}_{2}$ transformation. Each tetragonal particle release energy and expand to stable size in monoclinic form if a crack tries to form under stress. 


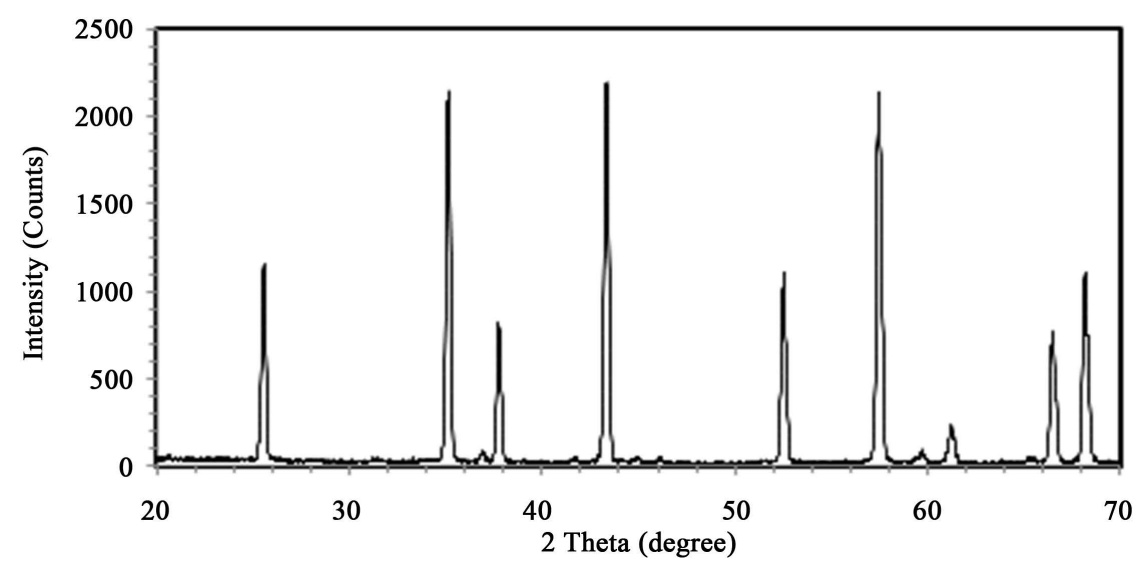

Figure 10. XRD pattern of sintered pure alumina $\left(\mathrm{Ts}=1580^{\circ} \mathrm{C}\right)$.

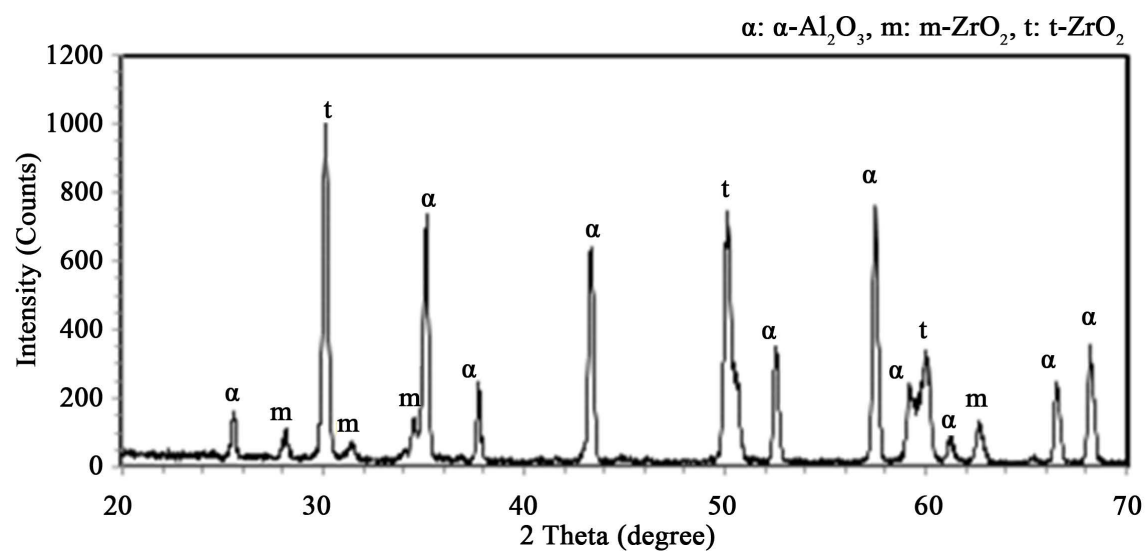

Figure 11. XRD pattern of sintered Alumina-Zirconia composite containing $20 \mathrm{vol} \%$ of $3 \mathrm{Y}-\mathrm{ZrO}_{2}\left(\mathrm{Ts}=1580^{\circ} \mathrm{C}\right)$.

\subsubsection{Variation of XRD Pattern with Zirconia Content}

The XRD patterns of Alumina-Zirconia composites containing 2, 5, 10, 15 and 20 vol\% stabilized $\mathrm{ZrO}_{2}$ and sintered at $1580^{\circ} \mathrm{C}$ for 2 hours are shown in Figure 12.

The XRD patterns demonstrate the effects of $\mathrm{ZrO}_{2}$ addition in presence of monoclinic or tetragonal content phases. Phases of $\alpha$-alumia (ICDD 089-7717)), monoclinic zirconia (037-1484) and tetragonal zirconia (ICDD 072-7115) were identified for all composites by XRD analysis.

From Figure 12 it is observed that though $\mathrm{t}-\mathrm{ZrO}_{2}\left(3 \mathrm{Y}-\mathrm{ZrO}_{2}\right)$ was used for composite preparation a significant peak of $\mathrm{m}-\mathrm{ZrO}_{2}$ was obtained. Peak of maximum intensity of $\mathrm{t}-\mathrm{ZrO}_{2}$ was obtained for composite containing 20 vol\% $3 \mathrm{Y}-\mathrm{ZrO}_{2}$. But intensity of $\mathrm{m}-\mathrm{ZrO}_{2}$ continuously increased with zirconia content. Low $\mathrm{ZrO}_{2}$ content is favorable to retain $\mathrm{t}-\mathrm{ZrO}_{2}$ due to the presence of more alumina matrix. So, intensity of $\mathrm{m}-\mathrm{ZrO}_{2}$ increased continuously.

Mixture of $\mathrm{t}-\mathrm{ZrO}_{2}$ and $\mathrm{m}-\mathrm{ZrO}_{2}$ contribute to increase strength and toughness of the composite. The extent of toughening achieved in the composites depend on the particle size of $\mathrm{Al}_{2} \mathrm{O}_{3}$ and $\mathrm{ZrO}_{2}$, volume fraction of $\mathrm{ZrO}_{2}$ retained in the metastable tetragonal phase as well as on the relative distribution of $\mathrm{Al}_{2} \mathrm{O}_{3}$ and 


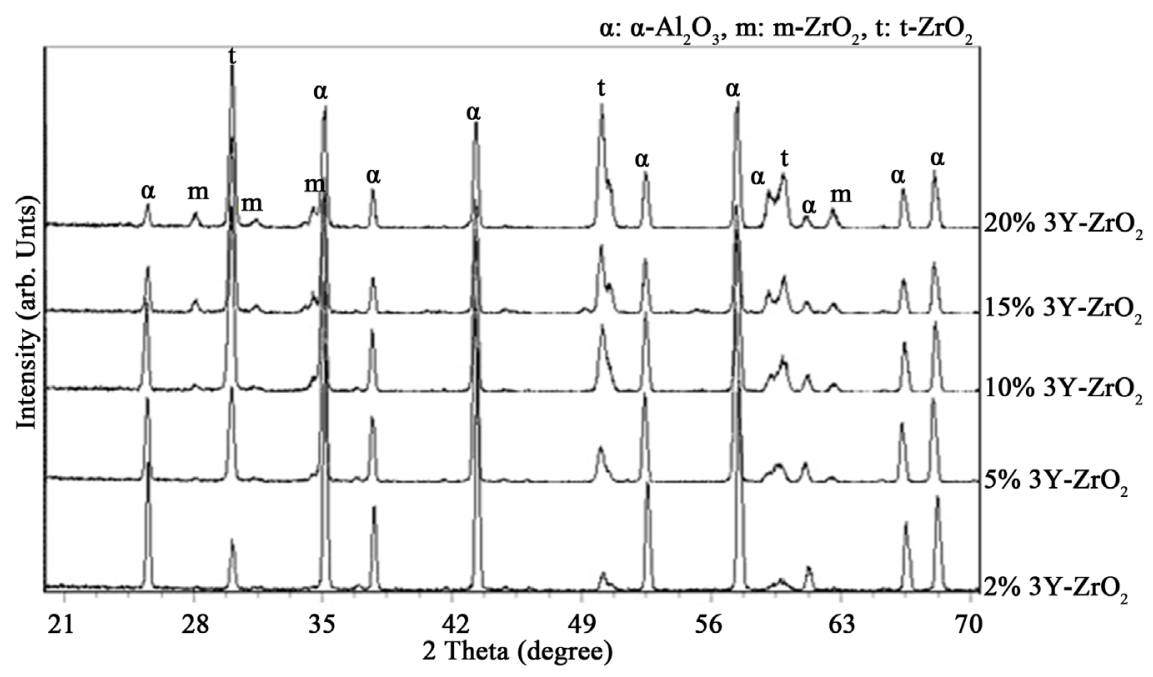

Figure 12. XRD patterns of Alumina-Zirconia composites containing 2 - 20 vol\% of $3 \mathrm{Y}-\mathrm{ZrO}_{2}\left(\mathrm{Ts}=1580^{\circ} \mathrm{C}\right)$.

$\mathrm{ZrO}_{2}$ in the matrix [20]. Finer particle size of both $\mathrm{Al}_{2} \mathrm{O}_{3}$ and $\mathrm{ZrO}_{2}$ will not only enhance the chances of a uniform $\mathrm{Al}_{2} \mathrm{O}_{3}$ and $\mathrm{ZrO}_{2}$ distribution, it also increases the possibility of $\mathrm{ZrO}_{2}$ being retained as metastable tetragonal phase [29].

\subsection{4. $\mathrm{t}-\mathrm{ZrO}_{2}$ Retention}

Although $3 \mathrm{Y}-\mathrm{ZrO}_{2}\left(\mathrm{t}-\mathrm{ZrO}_{2}\right)$ was used for preparation of Alumina-Zirconia composites in this study, peaks of considerable intensity of $\mathrm{m}-\mathrm{ZrO}_{2}$ was observed from Figure 12. When the vol\% of $3 \mathrm{Y}-\mathrm{ZrO}_{2}$ increased the peak intensity of $\mathrm{t}-\mathrm{ZrO}_{2}$ decreased, simultaneously the peak intensity of $\mathrm{m}-\mathrm{ZrO}_{2}$ increased. However it is confirm that tetragonal phase is indeed retained at room temperature as a metastable phase due to presence of hard alumina matrix around, and this phase is responsible for fracture toughness improvement by transformation toughening mechanism. The calculated volume fraction of $\mathrm{t}-\mathrm{ZrO}_{2}$ as a function of zirconia content is shown in Figure 13.

From Figure 13 it is observed that $100 \% \mathrm{t}-\mathrm{ZrO}_{2}$ retention was found for composites containing 2 and $5 \mathrm{vol} \% 3 \mathrm{Y}-\mathrm{ZrO}_{2}$. For Alumina-Zirconia composites containing 20 vol\% $3 \mathrm{Y}-\mathrm{ZrO}_{2}$ content $\mathrm{t}-\mathrm{ZrO}_{2}$ retention was found $87.5 \%$. In earlier works it was observed that, fraction of tetragonal phase increase when the quantity of $\mathrm{ZrO}_{2}$ decrease (30vol\% of tetragonal phase for $5 \mathrm{vol} \% \mathrm{ZrO}_{2}$, but only $5 \%$ of tetragonal phase for $20 \mathrm{vol} \%$ of $\mathrm{ZrO}_{2}$ ) [30] [31]. If the tetragonal phase is overstabilized, the stress required for transformation in the high stress region around a crack tip may be higher than the fracture stress. As a result the flexural strength of the composite will be low, similar to that of $\mathrm{Al}_{2} \mathrm{O}_{3}$. Our resultant Alumina-Zirconia composite consist a mixture tetragonal and monoclinic zirconia where tetragonal phase which is not overstabilized. So the composite is suitable for showing higher mechanical properties.

\subsection{Scanning Electron Microscopic (SEM) Analysis}

The microstructure of Alumina-Zirconia composite samples containing different 


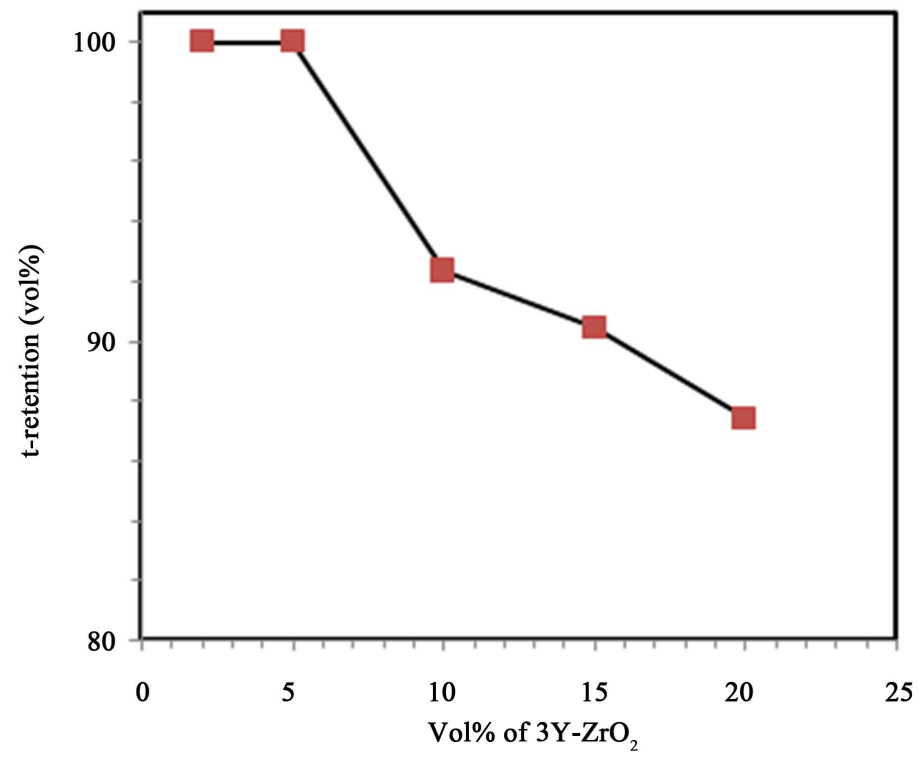

Figure 13. Tetragonal $\mathrm{ZrO}_{2}$ retention as a function of zirconia content.

vol\% 3Y- $\mathrm{ZrO}_{2}$ were examined using Scanning Electron Microscopy (SEM). Figures 14(a)-(c) show the SEM micrographs of Alumina-Zirconia composites. Comparatively dark and large grains are $\mathrm{Al}_{2} \mathrm{O}_{3}$ whereas bright and small grains are $\mathrm{ZrO}_{2}$. When $3 \mathrm{Y}-\mathrm{ZrO}_{2}$ was added, the grains become finer compared to that of pure $\mathrm{Al}_{2} \mathrm{O}_{3}$, as shown in Figure 14(b) and Figure 14(c). Observations show highly homogeneous microstructures without agglomerates, pores or abnormally grown alumina grains. The zirconia grains are well-distributed in the material and the alumina grains are surrounded by them.

There is interplay between densification and grain growth during solid state sintering of polycrystalline ceramics. Densification occurs by the flux of matter from the grain boundaries (the source) to the pores (the sink). Rapid densification requires that the diffusion distance between the source of matter and the sink be kept small, i.e., the grain size must remain small. Rapid grain growth causes a drastic reduction in the densification rate, so prolonged sintering time is needed to achieve the required density, which increases the possibility for abnormal grain growth to occur.

From Figure 14(b) and Figure 14(c), it can also be observed that $\mathrm{ZrO}_{2}$ particles are uniformly dispersed throughout the alumina matrix. A homogeneous distribution of zirconia throughout the alumina matrix as well as the typical intergranular location of zirconia at the grain boundaries of the alumina was observed. This result is similar to that published elsewhere [32]. As the amount of $3 \mathrm{Y}-\mathrm{ZrO}_{2}$ content increases, the $\mathrm{Al}_{2} \mathrm{O}_{3}$ grain size decreases significantly. The $\mathrm{ZrO}_{2}$ phase creates a pinning effect around $\mathrm{Al}_{2} \mathrm{O}_{3}$ grain and obstructs its growth. When $\mathrm{ZrO}_{2}$ is added with $\mathrm{Al}_{2} \mathrm{O}_{3}$, evenly distributed fine $\mathrm{ZrO}_{2}$ grains act as grain growth inhibitor and led to smaller $\mathrm{Al}_{2} \mathrm{O}_{3}$ grains. This is possibly due to increase in density as well as enhancement of mechanical properties.

It was observed that the microstructure became highly homogeneous and finer at sintering temperature $1580^{\circ} \mathrm{C}$. It can also be observed that the grain sizes of 


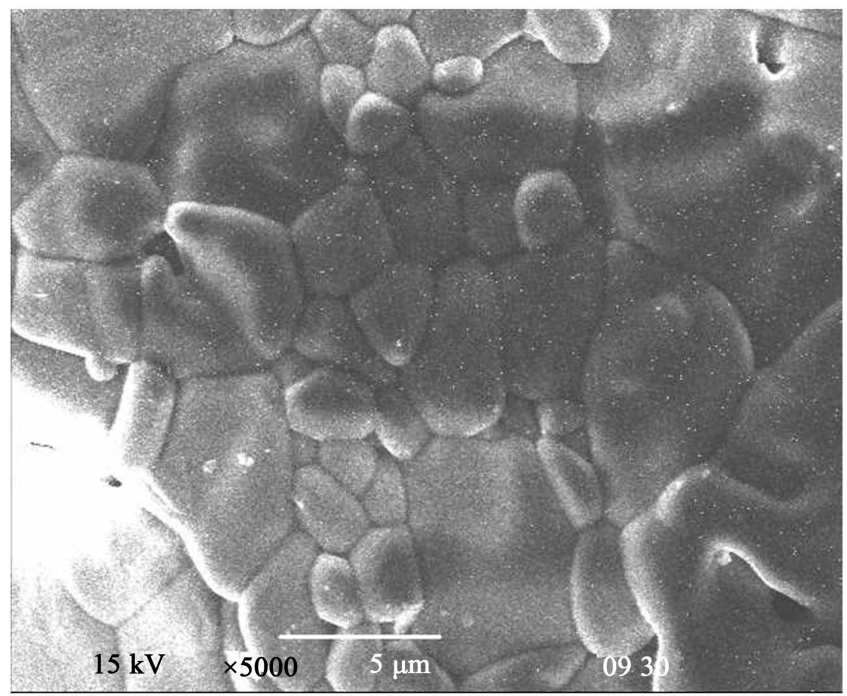

(a)

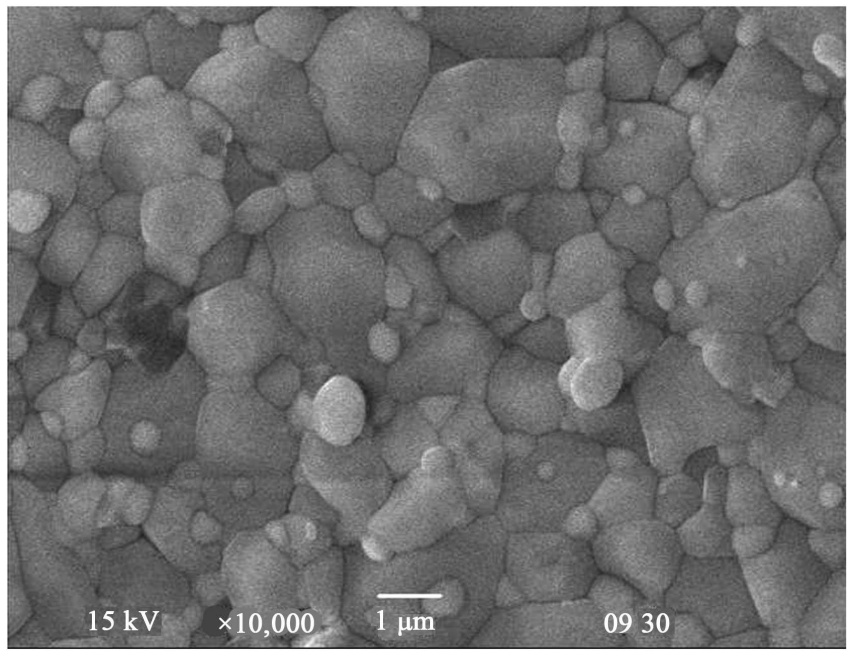

(b)

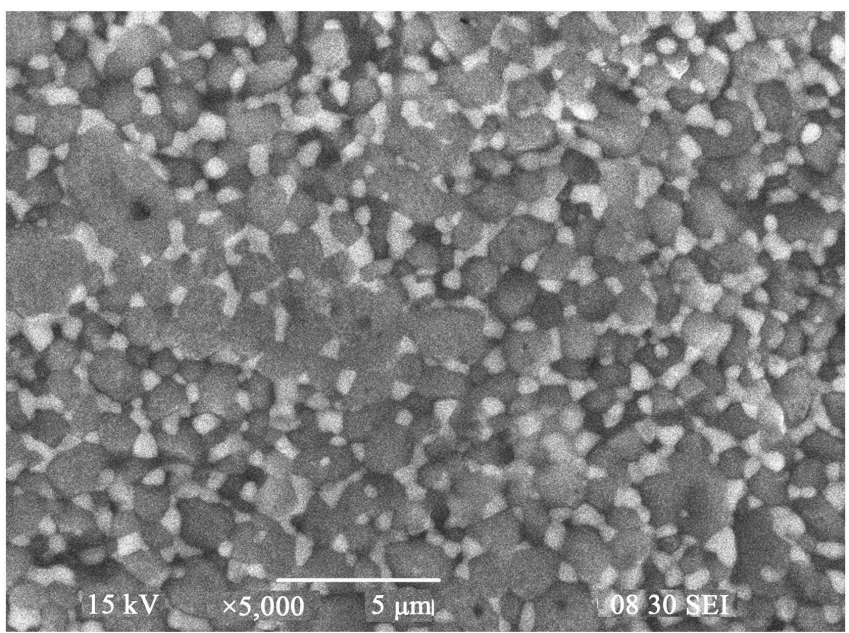

(c)

Figure 14. (a) Microstructure of sintered pure alumina pellet; (b) Microstructure of Alumina-Zirconia composite containing $90 \% \mathrm{Al}_{2} \mathrm{O}_{3}$ and $10 \% 3 \mathrm{Y}-\mathrm{ZrO}_{2}$; (c) Microstructure of Alumina-Zirconia composite containing $80 \% \mathrm{Al}_{2} \mathrm{O}_{3}$ and $20 \% 3 \mathrm{Y}-\mathrm{ZrO}_{2}$. 
$\mathrm{ZrO}_{2}$ increase and hinders the grain growth of $\mathrm{Al}_{2} \mathrm{O}_{3}$ at $1580^{\circ} \mathrm{C}$ which contributes to the lowering of porosity. A fine grain size and refined microstructure are necessary for improved mechanical properties especially for wear resistance of dental implant.

\section{Grain Size Analysis}

Figure 15 and Figure 16 show variation of alumina and zirconia grain size in Alumina-Zirconia composites with respect to $3 \mathrm{Y}-\mathrm{ZrO}_{2}$ content.

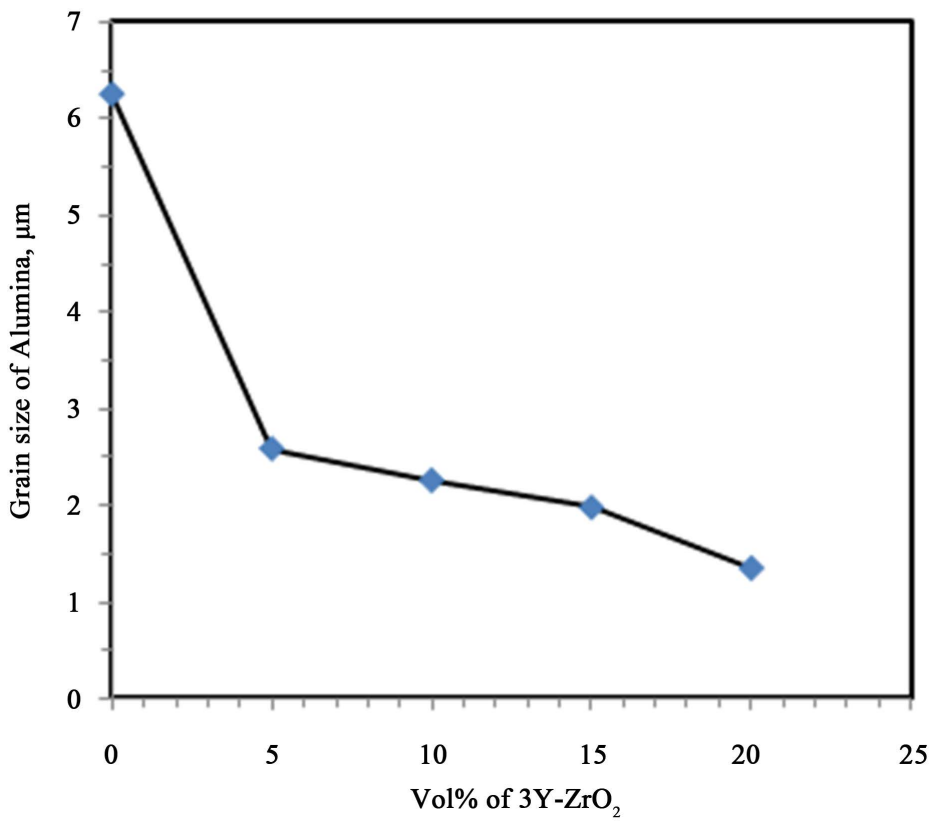

Figure 15. Effect of $3 \mathrm{Y}^{-} \mathrm{ZrO}_{2}$ content on grain size of alumina in Alumina-Zirconia composites.

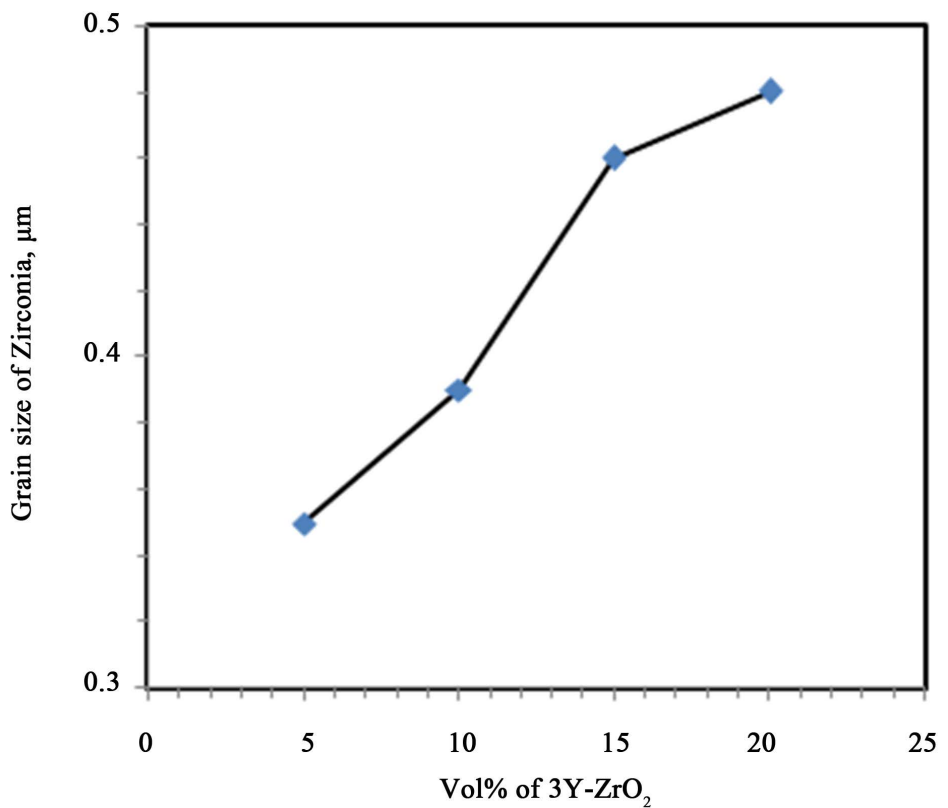

Figure 16. Effect of $3 \mathrm{Y}-\mathrm{ZrO}_{2}$ content on Zirconia grain size in alumina-zirconia composites. 
From Figure 15 it is observed that grain size of $\mathrm{Al}_{2} \mathrm{O}_{3}$ decreased significantly when a small amount of $3 \mathrm{Y}-\mathrm{ZrO}_{2}(5 \mathrm{vol} \%)$ is added with alumina. Further addition of $3 \mathrm{Y}-\mathrm{ZrO}_{2}$ led to decrease in alumina grain size slowly and linearly. In the present work maximum average grain size was obtained $6.25 \mu \mathrm{m}$ for pure alumina. For 5 vol\% of $3 \mathrm{Y}-\mathrm{ZrO}_{2}$ addition alumina grain size decreased to $2.58 \mu \mathrm{m}$. Minimum grain size of alumina was obtained $1.34 \mu \mathrm{m}$ for Alumina-Zirconia composite containing 20 vol\% of $3 \mathrm{Y}-\mathrm{ZrO}_{2}$. On the other hand, grain size of zirconia in Alumina-Zirconia composite increased linearly with zirconia content (Figure 16). In the present study minimum and maximum grain size of zirconia was obtained $0.35 \mu \mathrm{m}$ and $0.48 \mu \mathrm{m}$ for Alumina-Zirconia composite containing 5 vol\% and 20 vol\% $3 \mathrm{Y}-\mathrm{ZrO}_{2}$ respectively. The present results are harmonious with some previous works [9] [33]. The increase in density with zirconia content of Alumina-Zirconia composite may due to increase in zirconia grain size and decrease in alumina grain size.

\section{Conclusion}

In this present study, Alumina-Zirconia composites containing 0 - 20 vol\% $3 \mathrm{Y}-\mathrm{ZrO}_{2}$ have been synthesized successfully using powder compaction method. a-alumina, m-zirconia and t-zirconia phase were present in sintered composites. Addition of $3 \mathrm{Y}-\mathrm{ZrO}_{2}$ to alumina resulted composite materials with high density, high flexural strength and high fracture toughness. Microhardness and elastic modulus were found maximum for composite containing $5 \mathrm{vol} \%$ and $2 \mathrm{vol} \%$ of $3 \mathrm{Y}-\mathrm{ZrO}_{2}$, respectively. Flexural strength and fracture toughness were found maximum for composite containing $20 \mathrm{vol} \%$ of $3 \mathrm{Y}-\mathrm{ZrO}_{2}$. The characteristics of the composites exhibited better properties when compared with pure alumina. The ease of preparation of the composites and better properties support the viability of the process for industrial application.

\section{References}

[1] Fischer, H. and Marx, R. (2002) Fracture Toughness of Dental Ceramics: Comparison of Bending and Indentation Method. Dental Materials, 18, 12-19. https://doi.org/10.1016/S0109-5641(01)00005-7

[2] Grive, R.C. (1988) Vol. 24: Science and Technology of Zircinia III. In: Advance in Ceramics, American Ceramic Society, Ohio, p. 57.

[3] Wang, J. and Stevens, R. (1989) Zirconia Toughened Alumina (ZTA) Ceramics. Journal of Materials Science, 24, 3421-3440. https://doi.org/10.1007/BF02385721

[4] Becher, P.F. (1991) Advance in Design of Toughened Ceramics. Journal of the Ceramic Society of Japan, 99, 993-1001. https://doi.org/10.2109/jcersj.99.993

[5] Heuer, H., Lange, F.F. and Swin, M.V. (1986) Transformation Toughening-An Overview. Journal of the American Ceramic Society, 69, i-iv. https://doi.org/10.1111/j.1151-2916.1986.tb07400.x

[6] Claussen, N. (1976) Fracture Toughness of $\mathrm{Al}_{2} \mathrm{O}_{3}$ with an Unstabilised $\mathrm{ZrO}_{2}$ Dispersed Phase. Journal of the American Ceramic Society, 59, 49-51.

[7] Joyti, P., Devendra, K. and Kalyanj, M. (2011) Mechanical Behavior of AluminaZirconia Composite by Slurry Method. IJEST, 3, 1359-1367. 
[8] de Moraes, B., Elias, C.N., Filho, J.D. and de Oliva, L.G. (2004) Mechanical Properties of Alumina-Zirconia Composites for Ceramic Aboutments. Material Research. 7, 643-649. https://doi.org/10.1590/S1516-14392004000400021

[9] Tuan, W.H., Chen, R.Z., Wang, T.C., Cheng, C.H. and Kuo, S. (2002) Mechanical Properties of $\mathrm{Al}_{2} \mathrm{O}_{3} / \mathrm{ZrO}_{2}$ Composites. Journal of the European Ceramic Society, 22, 2827-2833. https://doi.org/10.1016/s0955-2219(02)00043-2

[10] Mills, H. and Blackburn, S. (2000) Zirconia Toughened Aluminas by Hydro-Thermal Processing. Journal of the European Ceramic Society, 20, 1085-1090. https://doi.org/10.1016/S0955-2219(99)00274-5

[11] Bleier, A. and Westmoreland, C.G. (1991) Effects of pH and Particle Size on the Processing of and the Development of Microstructure in Alumina-Zirconia Composites. Journal of the American Ceramic Society, 74, 3100-3111. https://doi.org/10.1111/j.1151-2916.1991.tb04307.x

[12] Suzuki, T., Sakka, Y., Nakano, K. and Hiraga, H. (1998) Effect of Ultrasonication on Colloidal Dispersions of $\mathrm{Al}_{2} \mathrm{O}_{3}$ and $\mathrm{ZrO}_{2}$ in $\mathrm{pH}$ Controlled Suspensions. JIM, 39, 682-689.

[13] Subbarao, E.C. (1981) Zirconia-An Overview. In: Heuer, A.H. and Hobbs, L.W., Eds., Advances in Ceramics, The American Ceramic Society, Westerville, 1-24.

[14] Heuer, A.H. (1991) Transformation Toughening. In: Brook, R.J., Ed., Concise Encyclopedia of Advanced Ceramic Materials, Pragamon Press, Oxford, 494-497.

[15] Evans, G. and Heuer, A.H. (1980) Review-Transformation Toughening in Ceramics: Martensitic Transformation in Crack-Tip Stress Fields. Journal of the American Ceramic Society, 63, 241-248.

[16] Green, D.J., Hannink, R.H.J. and Swan, M.V. (1989) Transformation Toughening of Ceramics. CRC Press, Boca Raton.

[17] Garve, R.C. (1988) Critical Size Effects in Alumina-Zirconia Alloys. In: Claussen, N., Ruhle, M. and Heuer, A.H., Eds., Advances in Ceramics, The American Ceramic Society, Columbus, 55-69.

[18] Hussen, M.M., Chowdhury, F.-U.-Z., Gafur, M.A. and Abdul Hakim, A.K.M. (2014) Structural and Mechanical Properties of Zirconia Toughened Alumina (ZTA) Composites. IJERT, 3, 2127-2134.

[19] Heuer, A.H. (1987) Transformation Toughening in $\mathrm{ZrO}_{2}$-Containing Ceramics. Journal of the American Ceramic Society, 70, 689-698.

[20] Bleier, A., Becher, F., Westmoreland, C.G. and Alexander, K.B. (1992) Effect of Aqueous Processing Conditions on the Microstructure and Transformation Behaviour in $\mathrm{Al}_{2} \mathrm{O}_{3}-\mathrm{ZrO}_{2}\left(\mathrm{CeO}_{2}\right)$ Composites. Journal of the American Ceramic Society, 75, 2649-2658. https://doi.org/10.1111/j.1151-2916.1992.tb05484.x

[21] Rana, R. (2009) Powder Processing, Densification Behavior, Microstructure and Mechanical Properties of $\mathrm{Al}_{2} \mathrm{O}_{3} 50$ vol\% $\mathrm{ZrO}_{2}$ Composites. PhD Thesis, National Institute of Technology, Rourkela.

[22] Pabst, W., Gregorova, E., Icha, G. and Tynova, E. (2004) Effective Elastic Properties of $\mathrm{Al}_{2} \mathrm{O}_{3}-\mathrm{ZrO}_{2}$ Composite Composites Part 4. Tensile Modulus of Porous $\mathrm{Al}_{2} \mathrm{O}_{3}$ and $\mathrm{ZrO}_{2}$. Composites-Silikáty, 48, 165-174.

[23] Anstis, G.R., Chantikul, Lawn, B.R. and Marshall, D.B. (1981) Critical Evaluation of Indentation Techniques for Measuring Fracture Toughness: I Direct Crack Measurements. Journal of the American Ceramic Society, 64, 533-538. https://doi.org/10.1111/j.1151-2916.1981.tb10320.x

[24] Rao, G., Iwasa, M., Tanaka, T., Kondoh, I. and Inoue, T. (2003) Preparation and Mechanical of $\mathrm{Al}_{2} \mathrm{O}_{3}-15 \mathrm{wt} \% \mathrm{ZrO}_{2}$ Composites. Scripta Materialia, 48, 437-441. 
[25] Wu, Y., Bandyopadhyay, A. and Bose, S. (2004) Processing of Alumina and Zirconia Nanopowders and Compacts. Materials Science and Engineering A, 380, 349-355.

[26] Hori, S., Somiya, H.Y. and Kaji, H. (1988) Change of Tetragonal Zirconia Content in Zirconia-Toughened Alumina by Hot Isostating Pressing. Journal of Materials Science Letters, 3, 242-244.

[27] Tan, K.S. and Ramalingam, H. (1997) The Elastic Moduli and Diametrical Compressive Fracture Stress of $\mathrm{Al}_{2} \mathrm{O}_{3}-\mathrm{ZrO}_{2}$ Ceramics. Journal of Physics D: Applied Physics, 30, 1029-1037. https://doi.org/10.1088/0022-3727/30/6/017

[28] De Azaa, A.H., Chevalier, J., Fantozzi, G., Schehl, M. and Torrecillas, R. (2002) Crack Growth Resistance of Alumina, Zirconia and Zirconia Toughened Alumina Ceramics for Joint Prostheses. Biomaterials, 23, 937-945.

[29] Grive, R.C. (1965) Occurrence of Meta-Stable Tetragonal Zirconia as a Crystallite Size Effect. The Journal of Physical Chemistry, 69, 1238-1243. https://doi.org/10.1021/j100888a024

[30] Heuer, A.H., Claussen, N., Kriven, W.M. and Ruhle, M. (1982) Stability of Tetragonal $\mathrm{ZrO}_{2}$ Particles in Ceramic Materials. Journal of the American Ceramic Society, 65, 642-650. https://doi.org/10.1111/j.1151-2916.1982.tb09946.x

[31] Claussen, N. and Jahn, J. (1978) Transformation of Tetragonal $\mathrm{ZrO}_{2}$ Particles in a Ceramic Matrix. Berichte der Deutschen Keramischen Gesellschaft, 55, 487-491.

[32] Biamino, S., Fino, M. and Badini, C. (2005) Alumina-Zirconia Yttria Nanocomposites Prepared by Solution Combustion Synthesis. Ceramics International Available on Line 31st May.

[33] Casellas, D., Afols, I.R., Llanes, L. and Anglada, M. (1999) Fracture Toughness of Zirconia-Alumina Composites. International Journal of Refractory Metals \& Hard Materials, 17, 11-22.

Submit or recommend next manuscript to SCIRP and we will provide best service for you:

Accepting pre-submission inquiries through Email, Facebook, LinkedIn, Twitter, etc. A wide selection of journals (inclusive of 9 subjects, more than 200 journals)

Providing 24-hour high-quality service

User-friendly online submission system

Fair and swift peer-review system

Efficient typesetting and proofreading procedure

Display of the result of downloads and visits, as well as the number of cited articles

Maximum dissemination of your research work

Submit your manuscript at: http://papersubmission.scirp.org/

Or contact msa@scirp.org 